\title{
What makes a species common? No evidence of density-dependent recruitment or mortality of the sea urchin Diadema antillarum after the 1983-1984 mass mortality
}

\author{
Don R. Levitan · Peter J. Edmunds · Keeha E. Levitan
}

Received: 1 July 2013 / Accepted: 19 December 2013 / Published online: 10 January 2014

(C) Springer-Verlag Berlin Heidelberg 2014

\begin{abstract}
A potential consequence of individuals compensating for density-dependent processes is that rare or infrequent events can produce profound and long-term shifts in species abundance. In 1983-1984 a mass mortality event reduced the numbers of the abundant sea urchin Diadema antillarum by 95-99\% throughout the Caribbean and western Atlantic. Following this event, the abundance of macroalgae increased and the few surviving D. antillarum responded by increasing in body size and fecundity. These initial observations suggested that populations of $D$. antillarum could recover rapidly following release from food limitation. In contrast, published studies of field manipulations indicate that this species had traits making it resistant to density-dependent effects on offspring production and adult mortality; this evidence raises the possibility that density-independent processes might keep populations at a diminished level. Decadal-scale (1983-2011) monitoring of recruitment, mortality, population density and size structure of $D$. antillarum from St John, US Virgin Islands, indicates that population density has remained relatively stable and more than an order of magnitude lower than that before the mortality event of 1983-1984. We detected no evidence of density-dependent mortality or recruitment since this mortality event. In this location, model estimates of equilibrium population density, assuming density-independent
\end{abstract}

Communicated by Jeff Shima.

D. R. Levitan $(\varangle) \cdot$ K. E. Levitan

Department of Biological Science, Florida State University,

Tallahassee, FL 32306-4295, USA

e-mail: levitan@bio.fsu.edu

P. J. Edmunds

Department of Biology, California State University, 18111

Nordhoff Street, Northridge, CA 91330-8303, USA processes and based on parameters generated over the first decade following the mortality event, accurately predict the low population density 20 years later (2011). We find no evidence to support the notion that this historically dominant species will rebound from this temporally brief, but spatially widespread, perturbation.

Keywords Density-independent regulation · Open populations · Population dynamics - Recruitment limitation $\cdot$ Sea urchin ecology

\section{Introduction}

Comparative studies have searched for, and found, life history traits associated with species being common or rare (Aizen and Patterson 1990; Murray et al. 2002). Alternately, abundances might be influenced by historical artifact; abundant species stay abundant because they produce abundant offspring. Can a single perturbation cause a fundamental shift in abundances, or does density-dependence provide a deterministic pull towards some species-environment dependent level (Eisenberg 1966; Myers et al. 1995) or result in Allee effects causing further reductions in abundances (Courchamp et al. 1999; Levitan and McGovern 2005)? Examining this issue is complicated, because often perturbations are not global, and local populations can be rescued from undisturbed source populations (Pulliam 1988) or the perturbation changes species interactions producing an alternative stable state (Sutherland and Karlson 1977). Here we examine a historically abundant species, decimated 30 years ago, that shows little or no sign of recovery, likely caused by persistent recruitment limitation.

Recruitment limitation occurs when density-independent processes keep populations below carrying capacity (Caley 
et al. 1996). Some populations can reach extraordinary population densities and still remain below carrying capacity if individuals are resistant to resource limitation (Andrew 1989; Levitan 1989), or if trade-offs between positive and negative density-dependent processes [e.g., resource and sperm limitation (Levitan 1991; Wahle and Peckham 1999)] are balanced. Traits such as body size plasticity and trade-offs between fertilization and fecundity which allow individuals to dampen or eliminate variation in survivorship and reproduction across densities, not only increase the likelihood of recruitment influencing adult abundances but also potentially reduce the probability, or rate, at which a population rebounds from a perturbation (Levitan 1989; Karlson and Levitan 1990).

Using decadal-scale monitoring data from St John, US Virgin Islands, we investigated local patterns of recruitment, mortality, and population density of Diadema antillarum, a formerly abundant species that underwent massive mortality throughout the western Atlantic and Caribbean in 1983-1984 (Lessios 1988). We test for evidence of densitydependent recruitment and mortality and then parameterize a density-independent population model (Karlson and Levitan 1990) based on pre-1991 data. The predictions from this model are compared with population densities 20 years later and patterns noted in a recent meta-analysis of Caribbean-wide data before and after the mortality event (Hughes et al. 2010). This approach allows us to explore why this species has not rebounded from the 1983-1984 mortality event in St John or at the regional scale within the tropical western Atlantic.

\section{Study organism}

The tropical sea urchin $D$. antillarum was abundant on shallow Caribbean reefs, often at densities of tens of individuals per meter squared, from at least the 1960s to the early 1980s (Lessios 1988) and perhaps for hundreds (Levitan 1992; Jackson 1997) to many thousands (Lessios et al. 2001) of years earlier. In the winter of 1983-1984, however, a species-specific pathogen reduced population densities by 96-99\% throughout the Caribbean and western Atlantic (Lessios 1988). Individual D. antillarum grow rapidly when food is abundant, but can shrink when population size increases and food becomes limited. This sea urchin therefore can resist starvation and remain reproductive under the severe food limitation that occurs at high population densities (Levitan 1989). Additionally, a trade-off exists between fecundity and fertilization. At low population densities, sea urchins have more resources and produce more gametes, but have lower fertilization success than the food-limited urchins at higher densities (Levitan 1991). Combined, these features level survivorship of $D$. antillarum and per capita zygote production across population densities, thereby reducing the probability of density-dependent population regulation and perhaps contributing to the maintenance of the high population densities that were ubiquitous in the Caribbean before 1983 (Levitan 1989).

\section{Materials and methods}

Initial monitoring program

In the summer of 1983, six months before mass mortality struck the area, five plots were established along the shallow (2-6 m) subtidal rocky reefs fringing Great Lameshur Bay and Little Lameshur Bay. These are sheltered bays on the south coast of St John, US Virgin Islands, within which D. antillarum population density and individual size structure were monitored (Levitan 1988a). From the summer of 1983 up to and including 1990 and again in 1992, D. antillarum population density and size structure were monitored within $1,000-\mathrm{m}^{2}(100 \mathrm{~m}$ along the shore $\times 10 \mathrm{~m})$ plots [for detail of sites and methods see Levitan (1988a)]. These plots were again monitored for $D$. antillarum from 2009 up to and including 2011. In these last 3 years, each plot was sampled by means of one hundred $1-\mathrm{m}^{2}$ haphazardly positioned quadrats, and size structure was determined by random selection of two points within the plot and measurement of the $50 \mathrm{D}$. antillarum closest to each point (100 individuals). If $<100 \mathrm{D}$. antillarum were found, all observed individuals within the plot were measured. In addition to this measure of size distribution for the full plot, the number of juvenile $D$. antillarum, defined as having banded spines and test diameter of $<20 \mathrm{~mm}$, was counted in each individual $1-\mathrm{m}^{2}$ quadrat.

In 1988, three 100-m transects were deployed along three depth contours, defined by the midpoint, shallow and deep ends of the 10-m-wide plot, for shallow, midpoint and deep-depth contours along each of the five plots. Along each transect, at ten random locations, a $10 \times 10$-cm algal scraping was collected with an airlift (as in Levitan 1988a). For each scraping the distance to the nearest $D$. antillarum was measured. Algal samples were dried and weighed to estimate algal biomass as a function of distance to the nearest $D$. antillarum.

\section{Secondary monitoring program}

D. antillarum has been monitored in Lameshur Bay since 1996 as part of a coral-reef monitoring program that began in 1987 [for site details see Edmunds and Witman (1991); Edmunds (2002, 2013)] and includes: (1) three 10-m transects at Yawzi point (9-m depth), (2) three 10-m transects at Tektite (14-m depth), (3) one transect (40 m long) at 5-6 m depth at each of five locations from 1996 and six 
locations from 1999 on the shallow fringing reefs between White Point and Cabritte Horn [sites used for the census of juvenile corals in Edmunds $(2002,2013)]$, and (4) one transect $(20 \mathrm{~m}$ long from 1996 up to and including 2000 and $40 \mathrm{~m}$ long from $2001 \mathrm{up}$ to and including 2011) at each of six locations (9-m depth) between White Point and Cabritte Horn [pooled random sites used for the analysis of benthic community structure in Edmunds (2013)]. Additional surveys for Diadema density were conducted from 1996 along four 20-m transects at Yawzi Point (9-m depth) that were first used to expand the spatial scale of ecological analyses following Hurricane Hugo in 1989 (Edmunds and Witman 1991) and subsequently have been censused annually. $D$. antillarum were counted annually within 2-m-wide bands along the aforementioned 21 transects. Two transects at the 5- to 6-m-depth contour (Donkey Bite and Tektite Cliffs) overlap with two sites in the initial monitoring program.

Recruitment, mortality, and predicted population densities

Annual per capita mortality rates were calculated for the initial monitoring sites as was done previously (Karlson and Levitan 1990, based on Ebert 1975) as

$\mu=K\left(S_{\infty}-S\right) /\left(S-S_{\mathrm{r}}\right)$

This is a modification of the Beverton-Holt model with $K$ defined as the negative natural logarithm of the slope of a Walford plot of test diameter at time 1 and size 1 year later $(K=0.71) . S_{\mathrm{r}}$ is the test diameter when recruits are first seen (set at $10 \mathrm{~mm}$ ), $S$ is the mean test diameter, and $S_{\infty}$ is the asymptotic body size based on the Walford plot [95 $\mathrm{mm}$ (see Karlson and Levitan 1990)]. We calculated mortality rate/individual per year for each plot and year using these values and the $S$ for that census. These calculations assume a stable size distribution and size-independent mortality (above a size of $10 \mathrm{~mm}$ ). For the first 2 years after the mass mortality (1984-1985) the size distribution was unstable and shifting to larger sizes (Levitan 1988a). The mortality rates estimated during this 2-year period are inflated (Karlson and Levitan 1990) and not used in analyses. The assumption of size-independent mortality of post-recruitment individuals is less certain. Estimates of mortality from a tethering experiment suggest that smaller individuals (test diameter $<30 \mathrm{~mm}$ ) had higher mortality than larger individuals with no mortality noted in animals $>40 \mathrm{~mm}$ (Clemente et al. 2007). The aforementioned results suggest that young, small individuals show size-dependent mortality until they reach 1 year or $>40-\mathrm{mm}$ test diameter. However, tethering experiments measure predation potential on individuals restricted from escape; they ignore behavioral modifications such as the cryptic behavior noted in juvenile D. antillarum (D. R. L., personal observation), and might not reflect actual predation pressure (Aronson et al. 2001).
If there is a deviation from the size-independent mortality assumption, it does not appear to severely bias projections of population size (Karlson and Levitan 1990; and see "Results").

Newly settled $D$. antillarum can grow 6-7 $\mathrm{mm} \mathrm{month}^{-1}$ (Randall et al. 1964) and individuals $<20$-mm test diameter are designated as juveniles [sexual maturity is achieved between 25 and $30 \mathrm{~mm}$ (Levitan 1988b)]. The size at 1 year post-settlement was estimated as $49 \mathrm{~mm}$. This value is the intercept of the Walford plot of size at $T+1$ year as a function of size at $T$ (Karlson and Levitan 1990) and is consistent with juvenile growth rates (Randall et al. 1964). Annual recruitment rate per meter squared $(R)$ was therefore defined as the number of individuals $<49 \mathrm{~mm}$ test diameter observed at each census. These values of recruitment and mortality were used to predict population densities in the next year as

$N_{\mathrm{t}}=N_{\mathrm{t}-1} e^{-\mu}+R$

as in Karlson and Levitan (1990). The equilibrium population density was estimated as

$N *=R /\left(1-e^{-\mu}\right)$

Equilibrium population density is not equivalent to carrying capacity; it results from the rate at which individuals recruit into the population and their longevity and is independent of density or resource availability. We examined the assumption of density-independent mortality and recruitment (see below). Predictions of future population sizes assume that recruitment and mortality remain constant over time, but this error can be measured in subsequent years. Karlson and Levitan (1990) used Eq. 2 to make predictions over 4 years (1985 up to and including 1988) across all five plots. Whereas each prediction differed by an average of $18 \%$ from the actual value, the average predicted density was within $5 \%$ of the actual value. The average match between predicted and actual values supports the validity of the assumptions of the model, such as size-independent mortality and a stable size distribution. Karlson and Levitan (1990) predicted an equilibrium density of $<1 \mathrm{~m}^{-2}$ and no evidence for a return to pre-mortality population densities.

\section{Testing for density-dependent recruitment and mortality}

We tested for density-dependent recruitment at two spatial scales. The first spatial scale was at the scale of $1-\mathrm{m}^{2}$ quadrats used from 2009 to 2011 in which we counted the number of adults and juveniles (test diameter $<10 \mathrm{~mm}$ ) to determine if the presence and abundance of adults were correlated with the number of juveniles at this spatial scale. Juvenile-adult interactions at this spatial scale might trigger density-dependent settlement or juvenile survivorship in at 
least two ways. First, if increased algal abundance since the mass mortality prevents successful settlement (Bak 1985), then settlement might be enhanced in areas with premortality levels of benthic algae. Adult $D$. antillarum are associated with intensive grazing halos at the $<1-\mathrm{m}$ spatial scale (see "Results") and could provide settlement habitat in a density-dependent manner at this spatial scale. Second, adult sea urchins are known to provide a spine canopy refuge for newly settled individuals in other species (Nishizaki and Ackerman 2006) and thus might increase juvenile survivorship in a density-dependent manner at this spatial scale. If spine canopies and grazing activities increase settlement and early survivorship, juveniles would be expected to be associated with the presence of adults. Such a pattern would not constitute proof of density dependence, since adults might simply be where a set number of recruits gather, but absence of this pattern indicates that density dependence cannot be detected.

We also tested for density-dependent recruitment at the larger spatial scale of our $1,000-\mathrm{m}^{2}$ plots. A potential mechanism at this spatial scale might be local retention of larvae produced at these sites. $D$. antillarum larvae develop for at least 30 days (Eckert 1998), which likely results in widescale dispersal; however, local retention has been noted even in species with prolonged development time (Taylor and Hellberg 2003). We tested local retention or other potential mechanisms of density-dependent recruitment at this $1,000-\mathrm{m}^{2}$ spatial scale. The total number of juveniles $\left(<20-\mathrm{mm}\right.$ test diameter) counted in the one hundred $1-\mathrm{m}^{2}$ quadrats for each $1,000-\mathrm{m}^{2}$ plot was tested as a function of the total number of adults counted, the site and year. Finding a positive correlation between recruits and adult densities is not strong evidence for density-dependence recruitment because of the confounding of high levels of recruitment leading to higher adult densities at a particular site. However, the absence of such an association would suggest that density dependence at this spatial scale cannot be detected.

We tested for density-dependent mortality by examining the estimated mortality rate for each plot and year as a function of population density in the prior year at the $1,000-\mathrm{m}^{2}$ scale. Because we are testing mortality as a function of prior density it avoids the confounding of mortality in a year influencing population size in that same year.

\section{Results}

Initial monitoring program

The long-term monitoring of shallow subtidal sites in St John revealed a decline in $D$. antillarum population densities from an average of $14.39 \mathrm{~m}^{-2}(\mathrm{SE}=2.43)$ before the
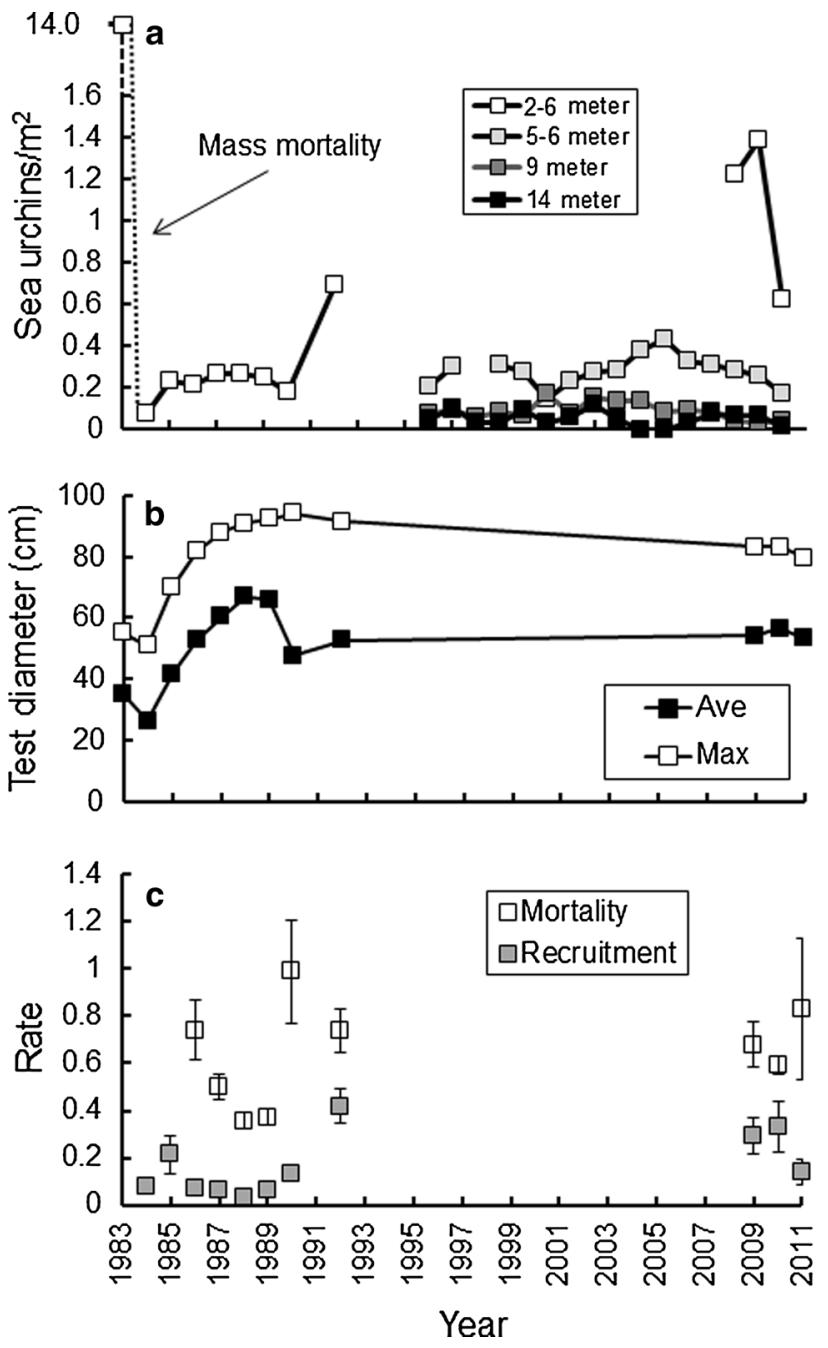

Fig. 1 a Population density of Diadema antillarum from the initial (2to 6-m depths, $n=5$, plots of $\left.1,000 \mathrm{~m}^{2}\right)$ and secondary $(n=5,9$ and 3 transects at 5- to 6-, 9- and 14-m depths, respectively) monitoring programs. Note break in the scale for 1983 census conducted before the 1983-1984 mass mortality. b Average (Avg) and maximum (Max) test diameter from the initial monitoring program $\left(n=5\right.$, plots of $1,000 \mathrm{~m}^{2}$; all sea urchins were measured if $<100$ individuals, at least 100 measured if $>100$ individuals). Decrease in size noted in 1990 coincides with Hurricanes Hugo. c Recruitment and mortality from the initial monitoring program $\left(n=5\right.$, plots of $1,000 \mathrm{~m}^{2}$; bars $\left.\mathrm{SE}\right)$

mass mortality to a low of $0.08 \mathrm{~m}^{-2}(\mathrm{SE}=0.02)$ measured in the summer of 1984. During the next year, densities increased to an average of $0.27 \mathrm{~m}^{-2}(\mathrm{SE}=0.11)$ in 1985 and fluctuated around $0.2 \mathrm{~m}^{-2}$ through the summer of 1990 (Fig. 1a). From 1990 to 1992 population densities tripled to $0.80 \mathrm{~m}^{-2}(\mathrm{SE}=0.12)$. After the 17 years' hiatus in monitoring at these sites, average densities increased to $1.01 \mathrm{~m}^{-2}(\mathrm{SE}=0.27)$ in 2009 and $1.15 \mathrm{~m}^{-2}(\mathrm{SE}=0.30)$ in 2010. In 2011, however, the density of $D$. antillarum dropped to $0.73 \mathrm{~m}^{-2}$ ( $\mathrm{SE}=0.31$ ), which is lower than those in 1992 (Fig. 1a). An ANOVA testing the effects of plot and year on population density indicated that both 
Table 1 ANOVA testing the effect of plot and year on population density

\begin{tabular}{lrcllr}
\hline Source & $d f$ & Type III SS & MS & $F$ & \multicolumn{1}{l}{$P$} \\
\hline Plot & 4 & 2.204 & 0.551 & 5.54 & 0.0012 \\
Year & 10 & 7.137 & 0.714 & 7.18 & $<0.0001$ \\
Error & 40 & 3.978 & 0.099 & & \\
Total & 54 & 13.319 & & & \\
\hline
\end{tabular}

A Duncan post hoc pair-wise test created two time groups significantly different from each other: pre-1991 population densities were significantly lower than post-1991 population densities. Within each time group there were no significant differences in population density

factors were significant (Table 1). A Duncan post hoc test indicated significant differences between two periods; densities within the period 1984-1990 were lower than those within the period 1992-2011 (Fig. 1a). Within each period no significant differences were apparent in densities across all sites.

To determine whether the differences in density of $D$. antillarum between the early (pre-1991) and late (post1991) periods could be attributed to changes in either mortality or recruitment, two-way ANOVAs were used to test the effects of time period (before or after 1991), plot, and their interaction, on recruitment (no. $\mathrm{m}^{-2}$ of individuals $<49-$ mm test diameter) and mortality (calculated with Eq. 1). The ANOVA on mortality indicated no significant interaction, and this interaction term was removed from the model. The subsequent test indicated a significant effect of

Table 2 Two-way ANOVA testing the effect of time period (years prior to 1991 and post-1991) and plot, and their interaction, on mortality and recruitment

\begin{tabular}{|c|c|c|c|c|c|}
\hline Source & $d f$ & Type III SS & MS & $F$ & $P$ \\
\hline \multicolumn{6}{|l|}{ Mortality $^{\mathrm{a}}$} \\
\hline Plot & 4 & 1.477 & 0.369 & 3.89 & 0.0094 \\
\hline Time period & 1 & 0.155 & 0.155 & 1.63 & 0.2096 \\
\hline Error & 39 & 3.704 & 0.095 & & \\
\hline Total & 44 & 5.336 & & & \\
\hline \multicolumn{6}{|l|}{ Recruitment $^{\mathrm{b}}$} \\
\hline Plot & 4 & 0.154 & 0.038 & 2.82 & 0.0397 \\
\hline Time period & 1 & 0.548 & 0.548 & 40.06 & $<0.0001$ \\
\hline Plot $\times$ time period & 4 & 0.174 & 0.044 & 3.19 & 0.0247 \\
\hline Error & 35 & 0.478 & 0.014 & & \\
\hline Total & 44 & 1.326 & & & \\
\hline
\end{tabular}

${ }^{a}$ For mortality, the interaction was not significant $(P=0.83)$ and was removed from the model

${ }^{b}$ For recruitment, because of the significant interaction, independent ANOVAs were conducted for each plot. Three of the five plots (NELL, SQST and WELL) had significantly lower recruitment $(P<0.05)$ pre-1991 compared to post-1991. The other two sites (DOBI, TECL) had non-significant trends in the same direction (pre1991 lower than post-1991) plot, but not time period (Table 2). The overall mean per capita mortality rate was 0.64 year $^{-1}(\mathrm{SE}=0.06)$. The highest mortality rates reached 0.83 year $^{-1}$ and 0.99 year $^{-1}$ in years after hurricanes affected the island (Earl in 2010 and Hugo in 1989). These hurricane effects also coincided with decreases in average test diameter and high mortality, as indicated by the presence of numerous Diadema tests on the shore after Hurricane Hugo (D. R. L., personal observation).

An ANOVA testing recruitment rate revealed a significant effect of time period (before or after 1991), plot, and a significant interaction (Table 2). Independent tests of time period for each plot indicated that some plots differed significantly in recruitment across time periods whereas others did not, but in every case mean recruitment was at least double (two- to 20-fold higher) in the later period. Overall, the increase in population density across all plots between 1990 and 1992 (Fig. 1a, c) appears to have been a function of increased recruitment and not reduced mortality. No evidence indicates that the recruitment rate has continued to increase since 1992. Over this period, the highest recruitment rate was recorded in 1992 (average across all sites of $0.42 \mathrm{~m}^{-2}$ year $\left.^{-1}\right)$ and the lowest in $2011\left(0.14 \mathrm{~m}^{-2}\right.$ year $\left.^{-1}\right)$. Population density, recruitment, and mortality of $D$. antillarum in St John vary across space and time, but no trend of increased population densities since the 1992 census is evident.

\section{Secondary monitoring program}

The census work conducted at 5- to 14-m depth and initiated in 1996 revealed a decrease in density of $D$. antillarum with depth, but no trend toward increasing densities over time (Fig. 1a; multiple regression $P<0.001$ for depth, $P=0.670$ for year). At 5- to 6-m depth, average densities fluctuated between a low of $0.15 \mathrm{~m}^{-2}(\mathrm{SE}=0.02)$ in 2001 and a high of $0.43 \mathrm{~m}^{-2}(\mathrm{SE}=0.14)$ in 2006. Average densities at the deeper sites fluctuated between 0.03 $(\mathrm{SE}=0.03)$ and $0.17 \mathrm{~m}^{-2}(\mathrm{SE}=0.07)$ at $9 \mathrm{~m}$ and between 0 and $0.12 \mathrm{~m}^{-2}(\mathrm{SE}=0.03)$ at $14 \mathrm{~m}$.

At the two sites that overlapped with the initial monitoring program, the density estimates overlap (Fig. 2). The initial monitoring program has overlapping but generally higher density estimates (average difference of $0.2 \mathrm{~m}^{-2}$ ) compared to the secondary monitoring program, but this is likely caused by the average depth differences in the two monitoring programs. The initial monitoring has a $10-\mathrm{m}$-wide belt with the deep end at 5-6 $\mathrm{m}$, while the secondary monitoring has a $2-\mathrm{m}$-wide belt centered at 5-6 m. Regardless of these subtle differences, there is no indication of large density shifts in the 17-year monitoring gap in the initial monitoring program at these sites. 

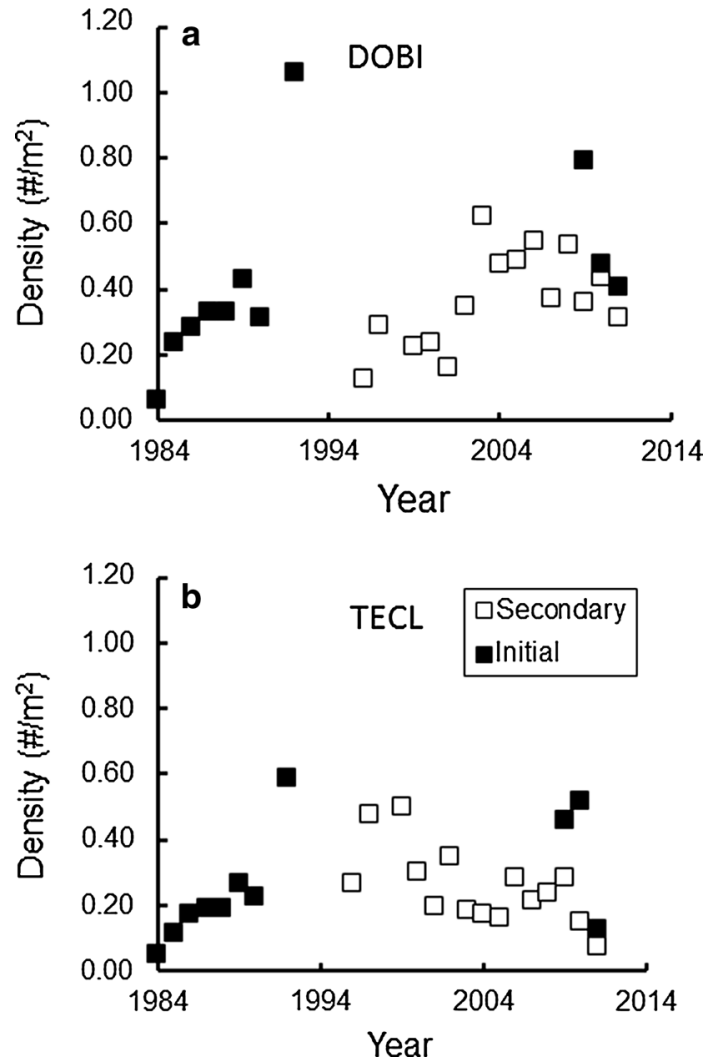

Fig. 2 Population density at the two census sites. a Donkey bite $(D O B I)$ and $\mathbf{b}$ Tektite cliffs (TECL) where the initial and secondary monitoring sites overlapped. All sea urchins counted in $1,000-\mathrm{m}^{2}$ plots from 1984 to 1992, all sea urchins counted within one hundred $1-\mathrm{m}^{2}$ quadrats per plot from 2009 to 2011

\section{Evidence of density dependence}

We examined patterns of recruitment at the spatial scale of the $1-\mathrm{m}^{2}$ quadrats used in 2009-2011 to determine whether new recruits were associated with clumps of adult $D$. antillarum. There was no relationship between the number of juvenile and adult $D$. antillarum at this spatial scale ( $n=1,500$ quadrats over the five plots and 3 years; Fig. 3a). These juveniles (test diameter of $<20 \mathrm{~mm}$ ) likely ranged in age from newly settled to 3 months post-settlement [growth rates of individual 4- to $11-\mathrm{mm}$ test diameter grow at a rate of 4-7 mm month ${ }^{-1}$ (Randall et al. 1964)]. A two-way analysis of covariance (ANCOVA) tested the number of juveniles as a function of the number of adults as the covariate, with plot and time and their interaction as the main effects. There was no significant interaction, and this was removed from the model. The reduced model revealed a significant effect of plot, but no significant effect of year or the covariate of adult density (Table 3). There is no evidence to support density-dependent recruitment at this spatial scale.

We examined whether $D$. antillarum might facilitate recruitment via their localized grazing activity. $D$. antillarum have a restricted home range in which they tend to return to the same crevice each dawn following evening grazing (Carpenter 1984). Algal weight measurements taken in $1988\left(1 \mathrm{~g} 100 \mathrm{~cm}^{-2}, \mathrm{SD}=0.89\right)$ were on average an order of magnitude higher than in 1983, prior to the mass mortality $\left[0.10 \mathrm{~g} 100 \mathrm{~cm}^{-2}, \mathrm{SD}=0.06\right.$ (Levitan 1988a)]. If there was no $D$. antillarum closer than $5 \mathrm{~m}$ to the site of algal collection, the average algal weight was $40 \%$ greater than if a sea urchin was present (1.4 vs. $0.99 \mathrm{~g}$ ). A regression of algal weight versus distance to the nearest $D$. antillarum, in the cases where a sea urchin was within $5 \mathrm{~m}$, indicated a significant positive relationship (Fig. 3b). When a Diadema was within $0.5 \mathrm{~m}$ of the algal scraping, the algal weight was similar to that from prior to the mass mortality. There is no indication that juveniles are associated with adults and the grazing halos they occupy.
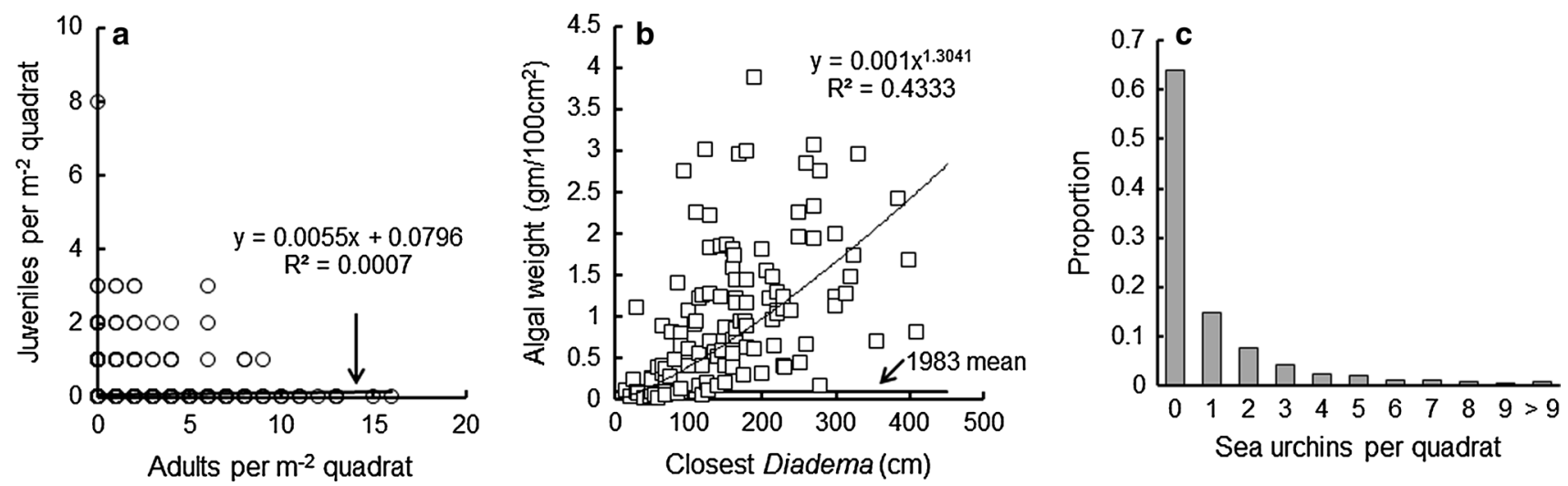

Fig. 3 a Relationship between the number of juvenile D. antillarum $\left(<20 \mathrm{~mm}\right.$ test diameter) and adults within 1,500 quadrats of $1 \mathrm{~m}^{2}$. The non-significant regression is based on all plots and years, and is supported by analysis of covariance (Table 3). b Algal dry weight as a function of the distance to the nearest $D$. antillarum $(n=121)$. Hori- zontal line near the bottom of the graph represents the average algae weight prior to the mass mortality in the summer of 1983. c Distribution of the number of $D$. antillarum within the 1,500 quadrats of $1 \mathrm{~m}^{2}$ from 2009, 2010 and 2011 censuses 
Table 3 Analysis of covariance (ANCOVA) of the number of juvenile sea urchins $(<20-\mathrm{mm}$ test diameter) as a function the main effects of plot and year with covariate of the number of adult sea urchins at either the 1 - or $1,000-\mathrm{m}^{2}$ spatial scale

\begin{tabular}{lrcrlr}
\hline Source & $d f$ & Type III SS & \multicolumn{1}{l}{ MS } & \multicolumn{1}{l}{$F$} \\
\hline 1-m $^{2}$ scale $^{\mathrm{a}}$ & & & & \multicolumn{1}{l}{$P$} \\
$\quad$ Plot & 4 & 4.5237 & 1.1309 & 7.01 & $<0.0001$ \\
Year & 2 & 0.7069 & 0.3534 & 2.19 & 0.1123 \\
Adult density & 1 & 0.4053 & 0.4053 & 2.51 & 0.1133 \\
Error & 1,492 & 240.8340 & 0.1614 & & \\
Total & 1,499 & 246.2473 & & & \\
$1,000-\mathrm{m}^{2}$ scale $^{\mathrm{b}}$ & & & & & \\
Plot & 4 & 418.196 & 104.549 & 4.77 & 0.0356 \\
Year & 2 & 74.393 & 37.197 & 1.70 & 0.2505 \\
Adult density & 1 & 27.599 & 27.599 & 1.26 & 0.2987 \\
Error & 7 & 153.334 & 21.905 & & \\
Total & 14 & 681.733 & & & \\
\hline
\end{tabular}

a At the $1-\mathrm{m}^{2}$ spatial scale, the interaction between site and year was not significant $(P=0.20)$ and was removed from the model

b At the $1,000-\mathrm{m}^{2}$ spatial scale there was no replication per plot and the interaction could not be tested

The distribution of sea urchins within $1-\mathrm{m}^{2}$ quadrats taken from 2009 up to and including 2011 (Fig. 3c) indicate that $35 \%$ of these plots had one or more $D$. antillarum that maintain (or are associated with) pre-mass mortality levels of algal abundance.

We also found no evidence of density-dependent recruitment at the scale of $1,000 \mathrm{~m}^{2}$ (Fig. 4a, b). An ANCOVA testing for the number of juveniles as a function of prior number of adults summed across all one hundred $1-\mathrm{m}^{2}$ quadrats, at each site for 2009, 2010 and 2011 resulted in a significant effect of site, but not year or the covariate of prior density (Table 3 ).

We examined patterns of per capita mortality (Fig. 4c, d) over a year as a function of plot, year and the population density at the start of each year with an ANCOVA. The first year was excluded because, as previously noted, the estimates of mortality in the first 2 years following the 1983-1984 mortality event were inflated due to an unstable body size distribution (inclusion of those years did not alter significance patterns reported below). The two main effects were plot and year with initial density as the covariate. Plot and year were significant, but not the covariate of initial density (Table 4); there was no evidence of density-dependent mortality over this density range and spatial scale.

In sum, although these results do not rule out the possibility of density-dependent recruitment or mortality, it does suggest that at a variety of spatial scales and densities, ranging over an order of magnitude, we could not detect an influence of density-dependent processes on population dynamics.

\section{Predicted and equilibrium densities of D. antillarum}

Predictions of population density for each site, based on the estimates of recruitment and mortality in the previous year, revealed a slight underestimate of population density (Fig. 5a). A reduced major axis regression
Fig. 4 Recruitment (a, b) and per capita yearly mortality (c, d) as a function of population density. Data are plotted with identity based on year $(\mathbf{a}, \mathbf{c})$ and plot $(\mathbf{b}, \mathbf{d})$. a, b Data are from one hundred $1-\mathrm{m}^{2}$ quadrats for each of the five plots and 3 years. c, $\mathbf{d}$ Data are from the full $1,000-\mathrm{m}^{2}$ plots for the five plots and 7 years. No evidence of density dependence was detected at this spatial scale
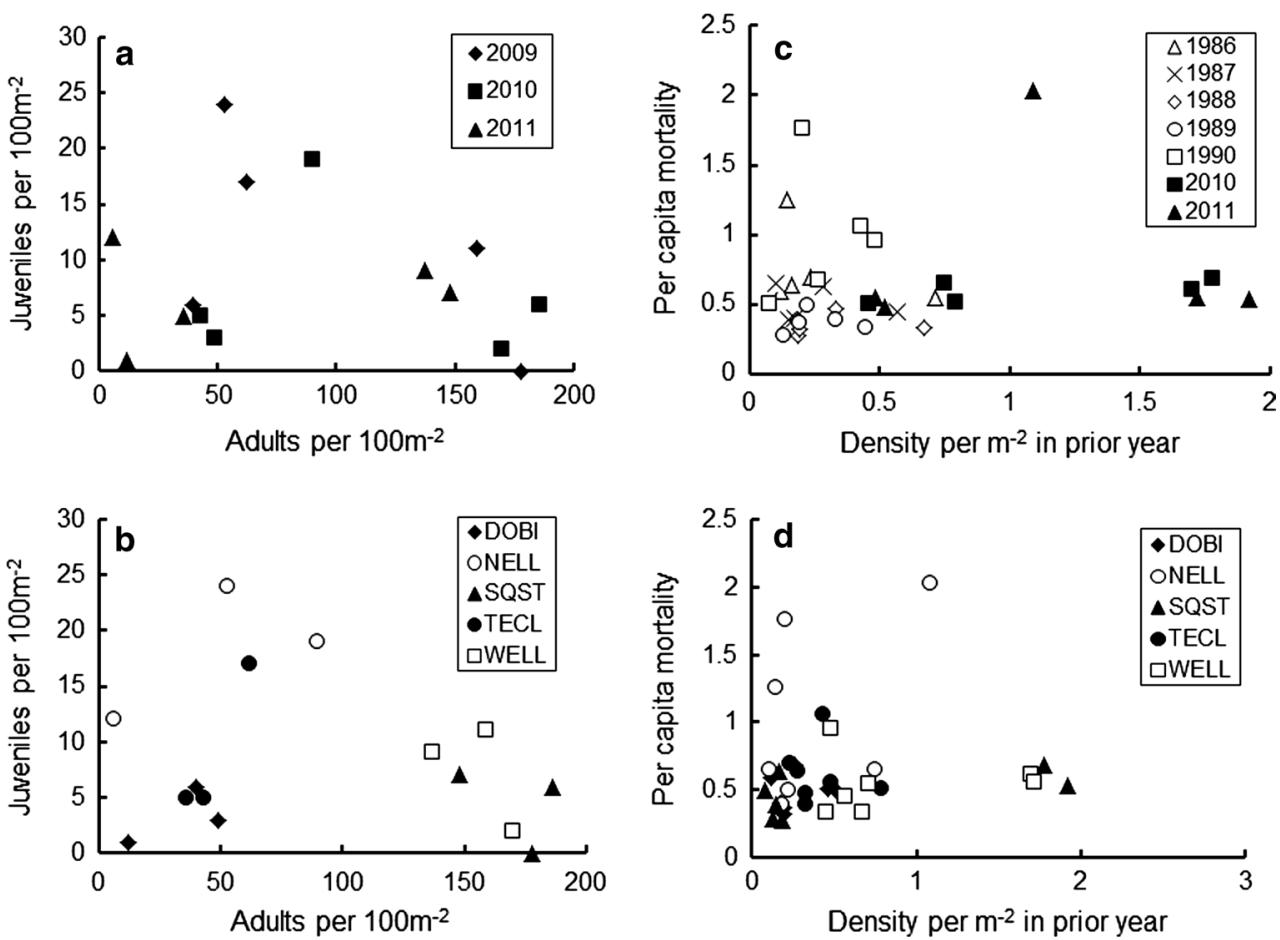
Table 4 ANCOVA of per capita mortality in 1 year as a function of the main effects of plot and year and the covariate of population density in the prior year

\begin{tabular}{lrllll}
\hline Source & $d f$ & Type III SS & MS & $F$ & $P$ \\
\hline Plot & 4 & 1.6388 & 0.4097 & 5.95 & 0.0019 \\
Year & 6 & 1.6029 & 0.2672 & 3.88 & 0.0081 \\
Prior density & 1 & 0.0990 & 0.0990 & 1.44 & 0.2429 \\
Error & 23 & 1.5844 & 0.0689 & & \\
Total & 34 & 4.9323 & & & \\
\hline
\end{tabular}

of observed population density as a function of predicted population density revealed a slope of 0.81 , which was significantly greater than 0 (Student's $t=12.20$ ) but $<1$ (Student's $t=2.77, t$ critical $=2.03, P<0.05$ ) indicating a slight overestimate of population density. These predictions account poorly for intermittent mortality events such as hurricanes. When years following hurricanes (1990, 2011) were removed from the model, the slope was steeper $(0.85)$ and significantly different from $0(t=8.94)$ but not 1 $(t=1.59, t$ critical $=2.05, P<0.05)$, indicating a better fit of predicted to actual $D$. antillarum densities.

Simulations of equilibrium population sizes for $D$. antillarum were made over a range of recruitment and mortality rates (0.01-10; Fig. 5b). Superimposed on this distribution are the range of estimates of equilibrium density based on the minimum and maximum recruitment $(0.004-0.65)$ and mortality (0.27-2.03) rates measured from 1986 to 2011 (Fig. 5b). All combined values of mortality and recruitment predicted equilibrium densities at least one order of magnitude less than were recorded before the mass mortality

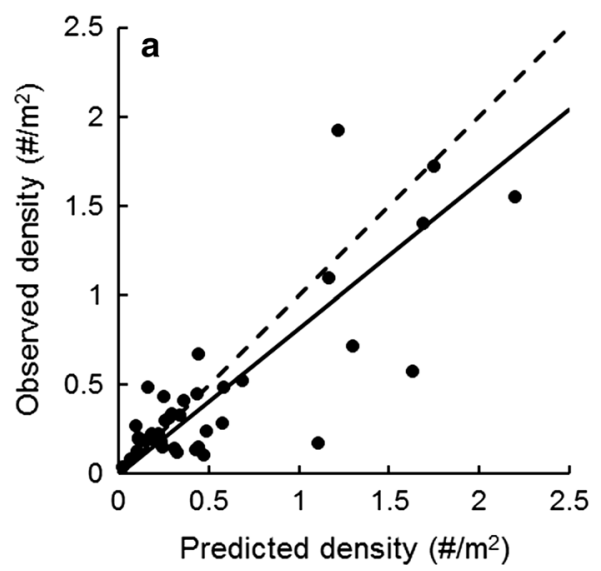

Fig. 5 a Population density per meter squared plotted as a function of predicted densities based on the previous year's estimate of recruitment and mortality for each location and year (excluding 1990 and 2009 because the previous years' data were missing; $n=40$ ). b Simulations of equilibrium densities as a function of recruitment rate $(x$-axis) and mortality rate (lines). Per capita annual mortality and annual recruitment per meter squared were varied independently from of 1983-1984 (Fig. 5b). The mean estimate of recruitment $(0.17, \mathrm{SE}=0.03)$ and mortality $(0.64, \mathrm{SE}=0.06)$ across all monitored years (1984-2011) and locations resulted in an equilibrium density of $0.36 \mathrm{~m}^{-2}$, with little variation $(\mathrm{SE}=0.05)$. Because recruitment rate increased significantly before and after 1991, predictions of future population size were based on estimates from 1992. Values for recruitment $\left(0.416\right.$ recruits $\mathrm{m}^{-2}$ year $\left.^{-1}\right)$ and mortality (0.736/individual per year) from 1992 provided an equilibrium population density of $0.80 \mathrm{~m}^{-2}$ ( $\mathrm{SE}=0.11$ across sites). This prediction is surprisingly close to, and not significantly different from, both the average population density recorded in our last (2011) census in St John of $0.73 \mathrm{~m}^{-2}$ (Student's $t, P=0.91$ ) and the average density across the 3 most recent census years (2009$2011=0.99 \mathrm{~m}^{-2}$, Student's $t, P=0.53$ ). Our data suggest D. antillarum in Great and Little Lameshur Bays rapidly reached a new equilibrium population density after the mass mortality of 1983-1984 and has remained, with minor fluctuations, at this new equilibrium.

\section{Discussion}

Although there was a hiatus in our initial monitoring program between 1992 and 2009, the average population densities of Diadema antillarum on the shallow reefs of St John in $1992\left(0.81 \mathrm{~m}^{-2}\right)$ and $2011\left(0.73 \mathrm{~m}^{-2}\right)$ suggest that no long-term shift in population density took place during the interval. This conclusion is supported by data collected during the intervening years over a range of depths, including two sites in common with the initial monitoring

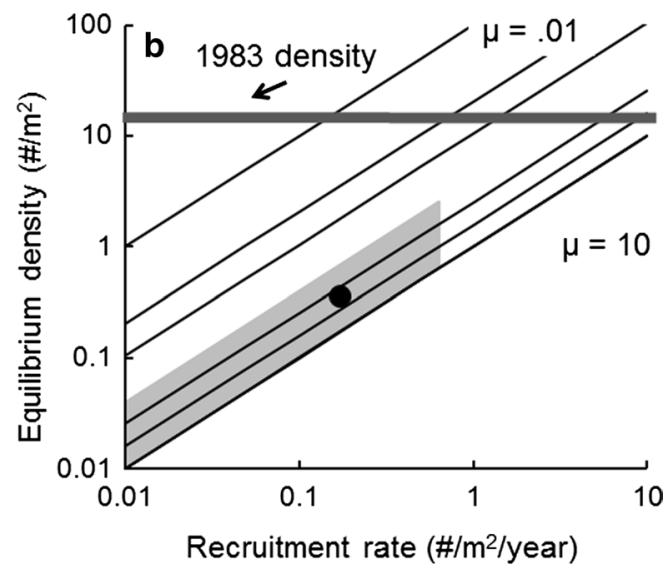

0.01 to $10(0.01,0.05,0.1,0.5,1,5$, and 10$)$. The two highest mortality rates produced similar lines and cannot be distinguished. The gray zone indicates the range of observed mortality and recruitment rates for any location and any time. The datum is the mean value, and the size of this symbol encompasses the SE for both recruitment and mortality rates. The dark gray horizontal bar represents the average pre-mortality density at these sites. Hash symbol Number 
program, which also show no evidence of population recovery. Although the densities of $D$. antillarum in shallow water in 2009 and 2010 (mean $1.1 \mathrm{~m}^{-2}$ ) were higher than those in 1992 (or 2011), they represent an increase of $<0.3 \mathrm{~m}^{-2}$ over the intervening 17 years, or less than two individuals $100 \mathrm{~m}^{-2}$ year $^{-1}$. Even if the 2011 decline in population density is ignored, there is no evidence from St John to support the notion that $D$. antillarum will return to pre-1984 densities in the next few decades or even hundreds of years. A nonlinear increase in population growth is certainly possible and could occur in the future, but over the nearly 30 years since the mass mortality, no evidence for an accelerating population recovery has been detected at these locations in St John.

The model was simple and lacked source and sink dynamics; however, it provides an expectation of population density for a given level of recruitment and mortality and it provides a means to examine the degree to which recruitment and mortality would have to change to induce a return to pre-mass mortality levels. The equilibrium population density predicted for the shallow reefs of St John on the basis of data from $1992\left(0.81 \mathrm{~m}^{-2}\right)$ is not significantly different from the population density recorded from 2009 to 2011. Densities of D. antillarum on St John have vacillated around 0.5 and $1.0 \mathrm{~m}^{-2}$ since the mass mortality, over an order of magnitude less than the $14 \mathrm{~m}^{-2}$ recorded in the early 1960s (Randall et al. 1964) and 1983 (this study) before the mortality event. After nearly 30 years, levels of recruitment and mortality for $D$. antillarum have not changed sufficiently to fuel a population recovery. The prediction made by Karlson and Levitan (1990) that $D$. antillarum was not on a path to recovery is still supported in $\mathrm{St}$ John.

A return to pre-mortality population densities would require a major change in mortality and/or recruitment rates. Given the average estimate of $D$. antillarum recruitment from 1992 up to and including 2011 for St John, mortality rates would have to decrease by almost two orders of magnitude (from 0.71 to 0.01 individuals $\mathrm{m}^{-2}$ years ${ }^{-1}$ ) to produce pre-mass-mortality densities. Our data reveal no evidence for a decrease in mortality rate since the mid-1980s and, thus no reason to expect mortality will decline in the future. Alternatively, given the average estimate of mortality from 1992 up to and including 2011, a recovery to 1983 levels would require an annual influx of 7.3 recruits $\mathrm{m}^{-2}$, which is 25 times the average rate recorded since 1992. Although mean recruitment increased from 0.094 recruits $\mathrm{m}^{-2}$ year $^{-1}$ before 1991 to 0.295 recruits $\mathrm{m}^{-2}$ year $^{-1}$ after 1991, it has not increased since 1992.

The model lacked density-dependent processes. However, we did not detect density-dependent mortality over the density range noted since the 1983-1984 mortality event. Moreover we did not detect an association between recruitment and adult densities at the $1-\mathrm{m}^{2}$ scale relevant to recruit-adult benthic interactions, or at the $1,000-\mathrm{m}^{2}$ scale that might be relevant to larger scale processes influencing larval settlement or juvenile survivorship. These results are consistent with the whole-reef manipulations by Lessios (1995), which demonstrated no difference in recruitment between pre- and post-mass mortality levels of adult density over two 4-year periods that controlled for site-specific recruitment effects. These results are not consistent with 5-day experiments conducted by Miller et al. (2007), which demonstrated that juvenile $D$. antillarum placed on $1-\mathrm{m}^{2}$ artificial reefs located on sandy substrate were retained in greater numbers on reefs with 12 vs. one adult. Levitan and Genovese (1989) constructed similar artificial reefs $\left(1 \mathrm{~m}^{2}\right.$ located in sandy substrate) stocked with only adult $D$. antillarum and noted a rapid migration off these tiny reefs and high predation by Cassis tuberosa, a sand-dwelling gastropod. Results such as Miller et al.'s (2007), suggest that density-dependent processes might operate under some conditions, and our results do not rule out the possibility of density dependence under some conditions. However, our results do suggest that over the range of population densities noted since 1984, variation in population size does not seem to influence the rate of recruitment or mortality at these sites.

Long-term monitoring of $D$. antillarum in Panama (Lessios 2005) and the Florida Keys (Chippone et al. 2013) also indicates that recovery has not occurred. Data from across the Caribbean provide an average population density for $D$. antillarum of $\sim 10 \mathrm{~m}^{-2}$ before the mass mortality, a reduction to $<0.1 \mathrm{~m}^{-2}$ following the mortality event, and then an increase to $<1 \mathrm{~m}^{-2}$ by the mid-1980s. Population densities of this echinoid have remained, on average, at these low levels through 2010 (Hughes et al. 2010). Higher population densities of ca. $5 \mathrm{~m}^{-2}$ have been occasionally reported [e.g., from Barbados in the mid-1980s (Hunte and Youglao 1988), Jamaica in the early 2000s (Edmunds and Carpenter 2001), Mexico in the mid-2000s (Jordan-Garcia et al. 2007), and six other Caribbean locations over 2003-2004 (Carpenter and Edmunds 2006)], but these same reports also document nearby islands, sites or zones with lower densities of $D$. antillarum. In addition, sampling in Cuba (Martín-Blanco et al. 2010) and Puerto Rico (Ruiz-Ramos et al. 2011) indicates average densities $<1 \mathrm{~m}^{-2}$. The sporadic reports of $D$. antillarum densities of around $5 \mathrm{~m}^{-2}$ following the mass mortality of 1983/1984 are markedly lower than densities of $>50 \mathrm{~m}^{-2}$ occasionally recorded before the mass mortality (e.g., Sammarco 1982). Thus, the average and extremes in population densities remain an order of magnitude lower following the mass mortality.

We cannot determine whether the aforementioned reports from sites with higher than average densities result 
from ephemeral recruitment or rising recruitment, because these reports do not come from long-term monitoring. At sites where predatory fishes are depleted by overfishing (e.g., Hay 1984), rare recruitment might generate persistent cohorts of adults. Larval settlement prior to and following the mortality event in Curacao indicated a drop from settlement peaks each year of 34-188 settlers $\mathrm{m}^{-2}$ 14 days $^{-1}$, to "virtually no recruitment" after March 1984 (Bak 1985). More recent measures from Curacao provide mean estimates of between 0.3 and 32 settlers $\mathrm{m}^{-2}$ 14 days $^{-1}$ (Vermeij et al. 2010). The results from Curacao are consistent with the pattern from St John, where we noted a two- to 20 -fold increase in recruitment between 1990 and 1992, but no increase thereafter (Fig. 1c). Because the study of Vermeij et al. (2010) took place in a single season, it is not possible to determine how recruitment has fluctuated between Bak's last census in 1984 to Vermeij et al's in 2005; maintaining high population densities might require the cumulative effect of repeated large pulses of settlers.

It is remarkable that $D$. antillarum was once abundant throughout the Caribbean, but following a single large mortality event, has remained at a density an order of magnitude lower for $>30$ years. Within 2 years of mass mortality, food availability increased, and D. antillarum body size and fecundity increased (Levitan 1988a, 1989). Despite reaching sexual maturity within a year and then spawning monthly thereafter (Lessios 1981, Levitan 1988b), a density-dependent population-level response has not been detected. The absence (or obscurity) of such a response does not rule out an eventual population recovery of $D$. antillarum, but it does suggest that density-independent processes and/or contradictory density-dependent factors have magnified the persistence of the disturbance created by the 1983-1984 mortality event. In the absence of density dependence, there is no deterministic mechanism for a population recovery; $D$. antillarum were approximately replacing themselves for at least 20 years prior to the mass mortality (1960-1983) and for the past 30 years following the mass mortality (1984-2011).

Alternate explanations for a lack of recovery include the persistence of the pathogen responsible for the mass mortality, and an altered environment. There were scattered reports of apparently the same disease that persisted for several years after 1983-1984 (Lessios 1988), but there is no evidence that the pathogen continues to kill $D$. antillarum. Circumstantial evidence for periodic disease outbreaks would include high temporal variance in local abundance and an unstable frequency distribution of sea urchin sizes. Subtle perturbations in these parameters were noted following hurricanes, but there has been no evidence of boom or bust cycles driving post-mortality populations in St John (Fig. 1a).
One of the most obvious change to the environment over the last 30 years is that reduced grazing pressure by low-density $D$. antillarum populations might reduce settlement success of this species. Bak (1985) noted a reduction in larval settlement on collecting panels as they became fouled by epibionts. However, Lessios (1995) conducted a large-scale reef manipulation and did not detect increased recruitment onto plots with pre-mortality levels of abundance. Our data indicate the presence of grazing halos surrounding adult $D$. antillarum in St John. The algal biomass within these halos is at pre-mass mortality levels (Fig. 3b), yet the presence of juvenile $D$. antillarum is not associated with the presence of adult $D$. antillarum at this spatial scale (Fig. 3a), or larger scales (Fig. 4). Single or small clumps of D. antillarum are associated with small grazing halos that occupied $20-35 \%$ of the substrate in our plots (Fig. 3c). If grazed substrate was both necessary and sufficient for successful recruitment, then these local patches should have attracted settlers and resulted in increased population size.

A return to pre-1984 population densities might depend on a slow accumulation of individuals on sites with low mortality, through periodic recruitment. These sites then might increasingly supply larvae to downstream locations. This was a potential outcome predicted following the pulse of recruits that arrived in Barbados shortly after the 1983 mortality (Hunte and Youglao 1988), but this outcome did not materialize. Likewise, the appearance of localized areas of moderate densities of $D$. antillarum in shallow water at multiple sites in the Caribbean in the early 2000s (Edmunds and Carpenter 2001; Carpenter and Edmunds 2006) appears not to have sustained a larger scale population recovery.

One more mechanism that might trigger a return to higher population densities would be if $D$. antillarum evolved to increase reproductive success at lower densities. Evidence from the temperate species Strongylocentrotus franciscanus indicate that this species has dramatically altered allele frequencies of gamete recognition proteins following the explosion of sea urchin abundances mitigated by the extirpation of sea otters from the Pacific Northwest (Levitan 2012). The allele that confers a two-fold fitness advantage at low population densities has been replaced by an allele that confers a similar two-fold advantage at high population densities. Selection for highly compatible recognition proteins along with selection on other gamete traits or adult traits that increase synchrony or clumping behavior would all increase the proportion of eggs fertilized at these lower population densities.

D. antillarum has yet to recover from the mass mortality event of 1983-1984 because it is resistant to density-dependent regulation and because the scale of the event removed potential source populations at high densities. If the mortality event had been confined to a local 
population, population recovery supported by recruitment from other source populations should have occurred in a few years (Lessios 1988). In the absence of localized high-density populations, population recovery can only be facilitated through the dynamics of the low-density metapopulation of this species throughout the Caribbean. D. antillarum provides a unique view of what can happen to a species when suddenly made rare across large spatial scales.

Acknowledgments We thank B. Bourgeaus, D. Brown, C.M. Cameron, N. B. Colvard, S. Genovese, D. H. Green, R. Habeeb, G. Horst, J. A. Idjadi, L. M. Jacobson, E. D. Keach, M. Maheigan, P. Marino, H. M. Putnam, L. Requa, C. L. M. Ross, M. Sewell, S.V. Vollmer, G. Wasserman, and C. Zilberberg for assistance in the field and C. S. Rogers, R. Boulon, V. Powell, S. Prosterman, and the Virgin Islands National Park for facilitating the research. This work was supported by NSF $03-43570$ and $08-41441$ to P. J. E., and is contribution no.203 of the marine biology program of California State University, Northridge.

\section{References}

Aizen MA, Patterson WA (1990) Acorn size and geographic range in the North American oaks (Quercus L.). J Biogeogr 17:327-332

Andrew NL (1989) Contrasting ecological implications of food limitation in sea urchins and herbivorous gastropods. Mar Ecol Prog Ser 51:189-193

Aronson RB, Heck KL Jr, Valentine JF (2001) Measuring predation with tethering experiments. Mar Ecol Prog Ser 214:311-312

Bak RPM (1985) Recruitment patterns and mass mortalities in the sea urchin Diadema antillarum. Proc Fifth Coral Reef Congr 5:267-272

Caley MJ, Carr MH, Hixon MA, Hughes TP, Jones GP, Menge BA (1996) Recruitment and the local dynamics of open populations. Annu Rev Ecol Syst 27:477-500

Carpenter RC (1984) Predator and population control of homing behavior in the Caribbean echinoid Diadema antillarum. Mar Biol 82:101-108

Carpenter RC, Edmunds PJ (2006) Local and regional scale recovery of Diadema promotes recruitment of scleractinian corals. Ecol Lett 9:271-280

Chippone M, Rutten LM, Miller SL, Swanson DW (2013) Recent trends (1999-2011) in population density and size of the echinoid Diadema antillarum in the Florida keys. Fla Sci 76:23-35

Clemente S, Hernandez JC, Toledo K, Brito A (2007) Predation upon Diadema aff. antillarum in barren grounds in the Canary Islands. Sci Mar 71:745-754

Courchamp F, Clutton-Brock T, Grenfell B (1999) Inverse density dependence and the Allee effect. Trends Ecol Evol 14:405-410

Ebert TA (1975) Growth and mortality of post-larval echinoids. Am Zool 15:755-775

Eckert GL (1998) Larval development, growth and morphology of the sea urchin Diadema antillarum. Bull Mar Sci 63:443-451

Edmunds PJ (2002) Long-term dynamics of coral reefs in St. John, US Virgin Islands. Coral Reefs 21:357-367

Edmunds PJ (2013) Decadal-scale changes in the community structure of coral reefs of St. John, US Virgin Islands. Mar Ecol Prog Ser 489:107-123

Edmunds PJ, Carpenter RC (2001) Recovery of Diadema antillarum reduces macroalgal cover and increases abundances of juvenile corals on a Caribbean reef. Proc Natl Acad Sci 98:5067-5071
Edmunds PJ, Witman JD (1991) Effect of hurricane Hugo on the primary framework of a reef along the south shore of St. John, US Virgin Islands. Mar Ecol Prog Ser 78:201-204

Eisenberg RM (1966) The regulation of density in a natural population of the pond snail, Lymnaea elodes. Ecology 47:889-906

Hay ME (1984) Patterns of fish and urchin grazing on Caribbean coral reefs: are previous results typical? Ecology 65:446-454

Hughes TP, Graham NAJ, Jackson JBC, Mumby PJ, Steneck RS (2010) Rising to the challenge of sustaining coral reef resilience. Trends Ecol Evol 25:633-642

Hunte W, Youglao D (1988) Recruitment and population recovery in the black sea urchin Diadema antillarum in Barbados. Mar Ecol Prog Ser 45:109-119

Jackson JBC (1997) Reefs since Columbus. Coral Reefs 16:S23-S32

Jordan-Garcia AG, Maldonado MA, Baker DM (2007) High abundances of Diadema antillarum on a Mexican reef. Coral Reefs 27:295

Karlson RH, Levitan DR (1990) Recruitment-limitation in open populations of Diadema antillarum: an evaluation. Oecologia 82:40-44

Lessios HA (1988) Mass mortality of Diadema antillarum in the Caribbean: what have we learned? Annu Rev Ecol Syst 19:371-393

Lessios HA (1995) Diadema antillarum 10 years after mass mortality: still rare, despite help from a competitor. Proc R Soc Lond B 259:331-337

Lessios HA (2005) Diadema antillarum populations in Panama twenty years following mass mortality. Coral Reefs 24:125-127

Lessios HA, Garrido MJ, Kessing BD (2001) Demographic history of Diadema antillarum, a keystone herbivore on Caribbean reefs. Proc R Soc Lond B 268:2347-2353

Levitan DR (1988a) Algal-urchin biomass responses following the mass mortality of the sea urchin Diadema antillarum Philippi at Saint John, US Virgin Islands. J Exp Mar Biol Ecol 119:167-178

Levitan DR (1988b) Asynchronous spawning and aggregative behaviour in the sea urchin Diadema antillarum Philippi. In: Burke R (ed) Proceedings of the 6th International Echinoderm Conference. Balkema, Rotterdam, pp 181-186

Levitan DR (1989) Density-dependent size regulation in Diadema antillarum: effects on fecundity and survivorship. Ecology 70:1414-1424

Levitan DR (1991) Influence of body size and population density on fertilization success and reproductive output in a free-spawning invertebrate. Biol Bull 181:261-268

Levitan DR (1992) Community structure in times past: influence of human fishing pressure on algal-urchin interactions. Ecology 73:1597-1605

Levitan DR (2012) Contemporary evolution of sea urchin gameterecognition proteins: experimental evidence of density-dependent gamete performance predicts shifts in allele frequencies over time. Evolution 66:1722-1736

Levitan DR, Genovese SJ (1989) Substratum-dependent predatorprey dynamics: patch reefs as refuges from gastropod predation. $\mathrm{J}$ Exp Mar Biol Ecol 130:111-118

Levitan DR, McGovern TA (2005) The Allee effect in the sea. In: Norse EA, Crowder LB (eds) Marine conservation biology. Island Press, Washington, pp 47-57

Martín-Blanco F, González-Sansón G, Pina-Amargós F, Clero-Alonso L (2010) Abundance, distribution and size structure of Diadema antillarum (Echinodermata: Diadematidae) in South Eastern Cuban coral reefs. Rev Biol Trop 58:663-676

Miller RJ, Adams AJ, Ebersole JP, Ruiz E (2007) Evidence for positive density-dependent effects in recovering Diadema antillarum populations. J Exp Mar Biol Ecol 349:215-222

Murray BR, Thrall PH, Gill AM, Nicotra AB (2002) How plant lifehistory and ecological traits relate to species rarity and commonness at varying spatial scales. Anim Ecol 27:291-310 
Myers RA, Barrowman NJ, Hutchings JA, Rosenberg AA (1995) Population dynamics of exploited fish stocks at low population levels. Science 269:1106-1108

Nishizaki TM, Ackerman JD (2006) Juvenile-adult associations in sea urchins (Strongylocentrotus franciscanus and S. droebachiensis): protection from predation and hydrodynamics in $S$. franciscanus. Mar Biol 151:135-145

Pulliam HR (1988) Sources, sinks and population regulation. Am Nat 132:652-661

Randall JE, Schroeder RE, Stark WA II (1964) Notes on the biology of the echinoid Diadema antillarum. Carib J Sci 4:421-433

Ruiz-Ramos DV, Hernandez-Delgado EA, Schizas NV (2011) Population status of the long-spined urchin Diadema antillarum in Puerto Rico 20 years after a mass mortality event. Bull Mar Sci 87:113-127
Sammarco PW (1982) Echinoid grazing as a structuring force in coral communities; whole reef manipulations. J Exp Mar Biol Ecol 61:31-55

Sutherland JP, Karlson RH (1977) Development and stability of the fouling community at Beaufort, North Carolina. Ecol Monogr 47:425-446

Taylor MS, Hellberg ME (2003) Genetic evidence for local retention of pelagic larvae in a Caribbean reef fish. Science 299:107-109

Vermeij JA, Debrot AO, van der Hal N, Bakker J, Bak RPM (2010) Increasing recruitment rates indicate recovering populations of the sea urchin Diadema antillarum on Curacao. Bull Mar Sci 86:719-725

Wahle RA, Peckham SH (1999) Density-related reproductive tradeoffs in the green sea urchin, Strongylocentrotus droebachienis. Mar Biol 134:127-137 